\title{
Pola Asuh Ibu Tiri dalam Membangun Karakter Anak Pra Sekolah
}

\author{
Siti Nurhaliza ${ }^{1}$, Yusmami $^{2}$ \\ ${ }^{12}$ Bimbingan dan Konseling Islam, Institut Agama Islam Negeri Langsa \\ sliza1458@gmail.com
}

$\begin{array}{ccc}\text { First received: } & \text { Revised: } & \text { Final Accepted: } \\ 30 \text { Maret } 2021 & 20 \text { April } 2021 & 28 \text { Mei } 2021\end{array}$

\begin{abstract}
Abstrac
This study discusses the Stepmother Parenting in Building the Character of Pre-School Children is experiencing various obstacles. This study aims to determine the parenting style of stepmothers in building the character of pre-school children and to find out the stepmother's obstacles in building the character of pre-school children. The type of approach used in this research is qualitative research. The results showed that stepmother parenting in building character in pre-school children is to educate them gently, we position them as our biological children so that their mental and character can be confident and as if they still have a biological mother. Parenting should not be authoritarian, because it will result in their mental and self-confidence will be down. The influence of the stepmother's parenting style on the child's character is very important, namely in the form of preventive action (prevention). Then in the form of repressive actions (active), as well as curative actions (supervision) on children's behavior both at home and outside the home. factors and barriers to stepmothers in building the character of pre-school are children who have a stepmother who are often feared by their friends playing in their environment, saying that the stepmother is very cruel, so that the psychology of the children becomes timid in front of their stepmother, then automatically, the stepmother's upbringing in building the children's character will experience obstacles
\end{abstract}

Keywords: Parenting, Stepmother, Character of Child.

\begin{abstract}
Abstrak
Penelitian ini membahas tentang Pola Asuh Ibu Tiri dalam Membangun Karakter Anak Pra Sekolah yang mengalami berbagai kendala. Penelitian ini bertujuan yaitu untuk mengetahui pola asuh ibu tiri dalam membangun karakter anak pra sekolah dan untuk mengetahui kendala ibu tiri dalam membangun karakter anak pra sekolah. Adapun jenis pendekatan yang digunakan didalam penelitian ini adalah penelitian kualitatif. Hasil penelitian menunjukkan Pola asuh ibu tiri dalam membangun karakter pada anak pra sekolah adalah mendidik mareka dengan lemah lembut, kita posisikan mereka sebagai anak kandung kita agar mental dan karakter mareka bisa percaya diri dan seolah-olah mareka masih memiliki ibu kandung. Pola asuh tidak boleh bersifat otoriter, karena akan berakibat mental dan rasa percaya diri mareka akan down. pengaruh pola asuh ibu tiri terhadap karakter anak sangat penting yaitu dalam bentuk tindakan preventif (pencegahan). Kemudian dalam bentuk tindakan repersif (aktif), serta tindakan kuratif (pengawasan) terhadap perilaku anak baik dirumah maupun diluar rumah. faktor dan hambatan ibu tiri dalam membangun karakter anak pra sekolah adalah anak-anak yang punya ibu tiri sering ditakuti oleh kawan kawan bermain di lingkungannya, dengan mengatakan bahwa ibu tiri sangat kejam,sehingga
\end{abstract}


membuat psikologi anak anak tersebut jadi penakut di hadapan ibu tirinya, maka secara otomatis, pola asuh ibu tiri dalam membangun karakter anak anak akan mengalami kendala

Kata Kunci: Pola Asuh, Ibu Tiri, Karakter Anak.

\section{PENDAHULUAN}

Anak merupakan manusia yang kondisinya belum mencapai taraf pertumbuhan dan perkembangan yang matang, maka segala sesuatunya berbeda dengan orang dewasa pada umumnya. Anak dapat dipandang sebagai individu yang baru mulai mengenal dunia. Ia belum mengetahui tata krama, sopan santun, aturan norma, etika dan berbagai hal tentang dunia. Oleh karena itu anak perlu dibimbing agar memahami berbagai hal tentang dunia dan isinya. Anak juga perlu dibimbing agar mampu memahami berbagai fenomena alam dan dapat melakukan keterampilanketerampilan yang dibutuhkan untuk hidup di masyarakat (Suyanto, S. 2005).

Peranan orangtua mendidik anak dalam rumah tangga sangatlah penting (Zubaedi, 2012; Anas, 2010). karena didalam rumah seorang anak mula-mula memperoleh bimbingan dan pendidikan dari orang tua. Tugas orangtua adalah sebagai guru atau pendidik utama dan pertama bagi anak-anaknya dalam menumbuhkan dan mengembangkan karakter bagi anak.

Salah satu kesempurnan tanggung jawab orang tua terhadap pendidikan anak mereka ialah selalu mengadakan evaluasi terhadap kekurangan dalam memenuhi hak-hak anak serta orang tua harus mampu menjadi bagian penting dalam diri anak (Chalidaziah, W. . Agama Islam membebankan tanggung jawab pendidikan kepada orang tua, bahkan Islam mengkhususkan keduanya dan menjadikannya sebagai suatu kewajiban bagi mereka. Hal ini sebagaimana firman Allah dalam AlQuran surat Lukman ayat 16

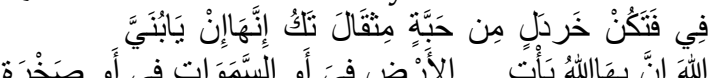

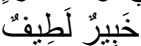

Artinya "Wahai anakku, sesungguhnya jika ada (sesuatu perbuatan) seberat biji sawi, dan berada di dalam batu karang atau di langit atau di bumi, niscaya Allah akan memberinya (balasan) sesungguhnya Allah Maha Halus lagi Maha Mengetahui."

Berdasarkan penjelasan di atas diketahui bahwa Orang tua merupakan pendidik utama dan pertama bagi anak. Pada umumnya pendidikan dalam keluarga tidak lahir secara terstruktur dan kesadaran mendidik melainkan karena secara kodrati memberikan secara alami membangun situasi pendidikan. Ibu adalah orang dan teman pertama yang didapatkan anak, oleh sebab itu anak akan meniru apa yang dilakukan ibu.

Dalam Islam pendidikan pertama yang dilakukan oleh orang Islam adalah pendidikan keluarga. Gunarsa (Ummi, 2008) mengatakan ibu adalah sebagai sentral dalam perkembangan awal anak, sedangkan kedudukan ayah hanya bersifat peran sekunder saja, suami semata-mata sebagai pendorong moral bagi istri, dan ibu juga bisa menentukan 
tingkah laku terhadap anak. Peran ibu sangatlah banyak, peranan ibu sebagai istri dan ibu dari anak anaknya, mengurus rumah tangga, sebagai pengasuh dan sebagai salah satu kelompok dan peranan sosialnya serta sebagai anggota masyarakat dari lingkungannya. Disamping itu, juga dapat berperan sebagai pencari nafkah tambahan bagi keluarga. Ibu tiri merupakan status yang disebabkan oleh anak-anak itu menjadi piatu yaitu ditinggal pergi oleh ibunya atau ibunya meninggal dunia (Ummi, 2008). Kemudian kedudukan ibu tiri ditempati oleh seorang subsitute atau pengganti ibu, dengan semua hak dan kewajiban seperti hak kewajiban ibu kandung sendiri.

Salah satu faktor yang mempengaruhi timbulnya kenakalan anak yaitu keteledoran kedua orang tua dalam memperbaiki diri anak, mengarahkan dan mendidiknya. Anak tidak boleh melupakan peran seorang ibu dalam memikul amanat dan tanggung jawab terhadap anak-anak yang berada di bawah pengawasannya dengan cara yang mendidik, mempersiapkan dan mengarahkan mereka (Zakiah, D. 2008; Djamarah, S, B. 2008).

Karakter yang berkualitas perlu dibentuk dan dibina sejak usia dini. Usia dini merupakan masa kritis bagi pembentukan karakter seseorang (Suyanto, S. 2005). Banyak pakar mengatakan bahwa kegagalan penanaman karakter pada seseorang sejak usia dini, akan membentuk pribadi yang bermasalah di masa dewasanya kelak. Selain itu, menanamkan moral pada generasi muda adalah usaha yang strategis. Hurlock (1991) menyatakan bahwa perkembangan anak pada masa pra sekolah sangat di pengaruhi oleh Pendidikan oleh lingkungan terdekat seperti orang tua dan pengasuhan yang di berikan di rumah. Jadi, orang tua mempunyai peran yang sangat penting dalam pendidikan dan pembentukan kepribadian, karakter seorang anak sejak usia dini.

Karakter merupakan unsur pokok dalam diri manusia yang dengannya membentuk karakter psikologi seseorang dan membuatnya berperilaku sesuai dengan dirinya dan nilai yang cocok dengan dirinya dalam kondisi yang berbeda-beda. Menurut Ngalim Purwanto (2001), kepribadian atau personality berasal dari bahasa latin, yaitu personare yang berarti mengeluarkan suara (to sound trough).

Istilah ini digunakan untuk menunjukkan suara dari percakapan seorang pemain sandiwara melalui topeng yang dipakainya. Fauzi, A (2003) mendefenisikan kepribadian sebagai berikut, bahwa kepribadian adalah keseluruhan pola atau bentuk tingkah laku, sifat-sifat, kebiasaan, kecakapan, bentuk tubuh, serta unsur-unsur psikopisik lainnya yang selalu menampakkan diri dalam kehidupan seseorang.

Adapun karakter yang berkembang pada masa prasekolah ialah kecenderungan initiative-guility (Hurlock, 1991). Pada masa ini anak telah memiliki beberapa kecakapan, dengan kecakapan-kecakapan tersebut dia terdorong melakukan beberapa kegiatan, tetapi karena kemampuan anak tersebut 
masih terbatas adakalanya dia mengalami kegagalan. Kegagalankegagalan tersebut menyebabkan dia memiliki perasaan bersalah, dan untuk sementara waktu dia tidak mau berinisiatif atau berbuat. Untuk itu sangat di butuhkan dukungan agar tidak terjadi penyimpangan pada tahap ini.

\section{METODE}

Penelitian ini menggunakan penelitian kualitatif deskriptif. Dalam penelitian ini penulis menggunakan data yang diperoleh langsung dari 4 responden. Dalam upaya mendapatkan keterangan yang lebih obyektif, kongkrit dan representative penelitian ini menggunakan observasi dan wawancara (Bungin, M, B. 2009).

\section{HASIL}

1. Pola Asuh Ibu Tiri Dalam Membangun Karakter Anak

Pola asuh Ibu tiri merupakan suatu sistem atau cara pendidikan, pembinaan yang diberikan oleh ibu tiri kepada anak tirinya. Dalam hal ini adalah pola asuh yang diberikan ibu tiri terhadap anak tiri adalah mengasuh dan mendidiknya penuh pengertian. Dan yang mempengaruhi pola asuh yang diberikan ibu tiri adalah pola asuh yang ditandai dengan cara mendidik anak-anaknya dengan aturan-aturan demokrasi, selain itu anak juga tidak dipaksa untuk berperilaku seperti dirinya (orang tua), kebebasan untuk bertindak atas nama diri sendiri tidak dibatasi. Anak sering diajak berkomunikasi dan diajak ngobrol, bercerita-cerita, bertukar pikiran dengan orang tua, orang tua tidak menganggap bahwa semua sikapnya dianggap benar sehingga diperlukan anak dimintai pertimbangan atas semua keputusan yang menyangkut permasalahan anakanaknya.

Hasil penelitian tentang Pola Asuh Ibu Tiri dalam Membangun Karakter Anak Pra Sekolah menunjukkan bahwa pola asuh yang digunakan ialah pola asuh authoritative, dalam mengasuh, membesarkan, merawat, dan mendidik anak tiri mereka bertindak/bersikap kepada anak selalu memberikan alasan kepada anak, Mereka juga berusaha mendorong untuk saling membantu dan bertindak secara objektif. Pola asuh yang diberikan oleh para orang tua juga cenderung tegas, tetapi kreatif dan percaya diri, mandiri serta memiliki tanggung jawab sosial. Selain itu orang tua juga selalu mendukung apa yang dilakukan oleh anak tanpa membatasi segala potensi yang dimilikinya serta kreativitasnya, namun tetap membimbing dan mengarahkannya. Selain itu pola Asuh anak tiri yang mempunyai dinamika tersendiri, yaitu mendidik mareka dengan lemah lembut, kita posisikan mareka sebagai anak kandung kita agar mental dan karakter mareka bisa percaya diri dan seolah-olah mereka masih memiliki ibu kandung.

Kewajiban orang tua adalah menolong anak dalam memenuhi kebutuhan hidup anak-anaknya, baik itu anak kandung maupun anak tiri, sebagai seorang ibu yang mengasuh anak-anak pra Sekolah, kita tidak boleh membeda bedakan antara anak kandung dengan anak tiri, akan tetapi memberikan perhatian yang sama, tanpa membeda 
bedakan status anak dalam keluarga, kita tidak boleh berlebih-lebihan dalam menolong sehingga anak tidak kehilangan kemampuan untuk berdiri sendiri dimasa yang akan datang.

2. Pengaruh Pola Asuh Ibu Tiri Terhadap Karakter Anak

Dalam keluarga orang tua bertanggung jawab memberikan pendidikan kepada anaknya dengan pendidikan yang baik berdasarka nilainilai akhlak dan spirituall yang luhur. Namun tidak semua orang tua dapat melakukannya. Buktinya dalam kehidupan di masyarakat sering ditemukan anak-anak nakal dengan sikap dan prilaku yang kurang baik. Pengaruh orang tua dalam mendidik anak cukup banyak, sebenarnya mendidik anak tidak hanya cukup bermodalkan watak kebapakan dan keibuan tanpa dukungan dengan kemampuan bagaimana cara-cara mendidik dengan baik. Karena kesalahan pola asuh yang dilakukan orang tua terhadap anaknya akan mendatangkan efek negative bagi perkembangan jiwa anak dalam kehidupan selanjutnya.

Berdasarkan hasil dari observasi dan wawancara yang peneliti lakukan pengaruh pola asuh ibu tiri terhadap karakter anak sangat penting yaitu dalam bentuk tindakan preventif (pencegahan) yaitu dalam bentuk menanamkan nilainilai agama seperti keimanan, ibadah, akhlak, disiplin dan prinsip-prinsip luhur lainnya. Kemudian dalam bentuk tindakan repersif (aktif) yaitu memberikan perhatian yang serius terhadap berbagai hal yang dibutuhkan dan tingkah laku anak, memberikan teladan yang baik dalam hal ucapan, pakaian,perilaku, ibadah, cara bergaul dengan orang lain, memberikan rasa aman, tentram dan harmonis dalam suasana kehidupan rumah tangga. Serta tindakan kuratif (pengawasan) terhadap perilaku anak baik dirumah maupun diluar rumah sehingga terbangun komunikasi yang aktif antar anggota keluarga.

3. Kendala Ibu Tiri Dalam Membangun Karakter Anak Pra Sekolah

Setiap usaha yang dilakukan oleh manusia tidak luput dari berbagai hambatan dan kendala-kendala yang ditemui. Hal itu pula yang dialami dalam proses membangun Karakter Anak Pra Sekolah yang dihadapi oleh para ibu tiri.

Menyangkut masalah hambatan dalam suatu penerapan adalah merupakan hal yang sering kali dihadapi oleh orang-orang yang terlibat di dalamnya. Demikian pula halnya dalam membangun karakter anak pra Sekolah melalui pola asuh ibu tiri ternyata tidak luput dari hambatan-hambatan yang merintangi, sehingga pola asuh ibu tiri dalam membangun Karakter Anak Pra Sekolah sedikit terkendala dengan psikologis.

Dalam hal ini anak pra Sekolah di Desa khususnya yang mempunyai ibu tiri terlihat agak kurang patuh dan lebih suka bermain main dengan kawankawan yang ada di lingkungannya. Ketika saat berada di rumah, anak-anak yang punya ibu tiri lebih banyak menyendiri dan segala sesuatu menunggu ayah nya pulang, karena para anak-anak yang di asuh oleh ibu tiri 
kurang terbuka dalam berkomunikasi dengan ibu tirinya sehingga anak-anak pra sekolah yang punya ibu tiri cenderung tertutup. Perlu diketahui bahwa ketika bermain dengan teman sebaya, anak-anak yang punya ibu tiri sering ditakuti oleh kawan-kawan bermain di lingkungannya, dengan mengatakan bahwa ibu tiri sangat kejam, sehingga membuat psikologi anak-anak tersebut jadi penakut di hadapan ibu tirinya, hal ini seperti yang di sampaikan oleh salah seorang ibu tiri yang mengasuh anak tirinya, kurangnya respek anak terhadap ibu tiri serta sebagian anak-anak terlalu manja serta merengek karena terhasut kawannya saat bermain di dalam lingkungan anak-anak yang nakal dan lingkungan kumuh.

\section{PEMBAHASAN}

Sebagai tujuan penelitian ini untuk mendeskripsikan pola asuh ibu tiri dalam membangun karakter anak pra sekolah maka pada bagian ini akan dianalisis data yang telah diperoleh melului wawancara menggunakan metode analisis deskriptif.

1. Pola asuh ibu tiri dalam membangun karakter anak pra sekolah Berdasarkan data yang diperoleh oleh penulis melalui wawancara yang dilakukan pada ibu tiri maka diperoleh hasil bahwa pola asuh yang digunakan ialah pola asuh authoritative. Adapun bentuk-bentuk pola asuh authoritative yang dilakukan ibu tiri dalam membangun karakter anak pra sekolah adalah sebagai berikut :

Pertama dalam mengasuh, membesarkan, merawat, dan mendidik anak tiri mereka bertindak/bersikap kepada anak selalu memberikan alasan kepada anak karena pada masa pra sekolah perkembangan kognitif awal anak termasuk dalam stadium pra operasional, dimana cara berfikirnya masih bersifat egosentris, terpusat, irraversibel, kreatif, bebas dan penuh imajinasi, pengetahuan tentang dunia luar meningkat dan ada keinginan kuat untuk belajar bahasa dan berbicara. maka dari itu ibu tiri memberikan pemahaman kepada anak tiri mereka tujuannya agar anak tersebut memahami dan mengerti apa yang dilakukan itu untuk kebaikannya (Ansori, M \& Firdaus, A, R. 2008; Megawati, R. 2004).

Kedua, mereka juga berusaha mendorong untuk saling membantu dan bertindak secara objektif, perhatian dan kontrol terhadap prilaku anak. Pada masa pra sekolah ingatan anak menjadi kuat sekali, suka menghafal, mengalami masa belajar dan mulai memperhatikan sekeliling dengan objektif, namun masih dikelilingi oleh khayalan. Karena itu dalam pengajaran membutuhkan integrasi dari beberapa indra sekaligus. Mengajar anak haruslah pada saat anak berada pada teachable moment yaitu saat tepat untuk mengajar (Ummi, 2008).

Ketiga pola asuh yang diberikan oleh para orang tua juga cenderung tegas, tetapi kreatif dan percaya diri, mandiri serta memiliki tanggung jawab sosial. tujuannya agar si anak tidak terlalu egois karena pada masa pra sekolah emosional anak bersifat egosenteris serta agar si anak tidak terlalu bergantung kepada orangtuanya maupun orang lain (Suyanto,S. 2005). 
Keempat juga selalu mendukung apa yang dilakukan oleh anak tanpa membatasi segala potensi yang dimilikinya serta kreativitasnya, walaupun si anak di berikan kebebasan namun ibu tiri di desa tetap membimbing dan mengarahkannya. Selain itu ibu tiri juga memberi nasehat, memberikan arahan terhadap anak dalam mengambil suatu pilihan, supaya si anak tadi bisa lebih bertanggung jawab lagi dalam hal apapun. Selain itu ibu tiri juga mendidik mareka dengan lemah lembut, ibu tiri juga memposisikan mereka sebagai anak kandungnya, agar mental dan karakter mareka bisa percaya diri dan seolah-olah mareka masih memiliki ibu kandung. Pola asuh tidak boleh bersifat otoriter, karena akan berakibat mental dan rasa percaya diri mareka akan down.

2. Pengaruh pola asuh ibu tiri terhadap karakter anak

Berdasarkan hasil dari observasi dan wawancara yang peneliti lakukan pengaruh pola asuh ibu tiri terhadap karakter anak dapat dianalisis yaitu pertama dalam bentuk tindakan preventif (pencegahan) yaitu dalam bentuk menanamkan nilai-nilai agama seperti keimanan, ibadah, akhlak, disiplin dan prinsip-prinsip luhur lainnya. Memberikan contoh perbuatan yang baik seperti tutur bahasa yang baik, mengucapkan salam apabila masuk rumah. Karena pada masa pra sekolah makin berkembangnya fungsi indra anak dalam mengadakan pengamatan (Anas, S., \& Alkrieehie, I. 2010).

Kedua dalam bentuk tindakan repersif (aktif) yaitu memberikan perhatian yang serius terhadap berbagai hal yang dibutuhkan dan tingkah laku anak, megawangi mengemukakan ada beberapa kesalahan orang tua dlam mendidik anak yang dapat mempengaruhi perkembangan kecerdasan emosi anak sehingga berakibat pula pada pembentukan karakter anaknya, yaitu orang tua kurang menunjukkan ekspresi kasih saying baik secara verbal maupun fisik, orang tua terlalu sibuk sehingga kurang meluangkan waktu yang cukup untuk anaknya, bersikap kasar secara verbal, bersikap kasar secara fisik, terlalu memaksa anak untuk menguasai kemampuan kognitif secara dini serta tidak menanamkan good karakter kepada anak. Syaodih, S, N (2006) mengemukakan masa pra sekolah ditandai adanya kecendrungan initiativeguility. Pada masa ini anak telah memiliki beberapa kecakapan, dengan kecakapankecakapan tersebut dia terdorong melakukan beberapa kegiatan, tetapi karena kemampuan anak tersebut masih terbatas adakalanya dia mengalami kegagalan. Kegagalan-kegagalan tersebut menyebabkan dia memiliki perasaan bersalah, dan untuk sementara waktu dia tidak mau berinisiatif atau berbuat, maka dari itu ibu tiri memberikan teladan yang baik dalam hal ucapan, pakaian, perilaku, ibadah, cara bergaul dengan orang lain, memberikan rasa aman, tentram dan harmonis dalam suasana kehidupan rumah tangga. Ibu tiri juga memberikan kasih sayang yang sama seperti anak kandung mereka sendiri, membimbing tata cara beribadah seperti mengajarkan sholat lima waktu, 
mengajarkan huruf hijaiyah serta mengajarkan berprilaku terhadap teman dan orang yang lebih tua dari si anak.

$$
\text { Ketiga tindakan kuratif }
$$

(pengawasan) terhadap perilaku anak baik dirumah maupun diluar rumah sehingga terbangun komunikasi yang aktif antar anggota keluarga. Ibu-ibu tiri juga memberitahu kepada anak mereka ketika dia bergaul dengan lingkungan sekitarnya itu boleh-boleh saja, tetapi dalam bergaul itu tidak merugikan diri sendiri dan orang lain, Djamarah, S, B. (2004) mengatakan dalam kaitannya dengan perkembangan sosial anak, pergaulan adalah sesuatu kebutuhan untuk memperkembangkan aspek sosial selain itu mereka juga menegur anakanaknya ketika sang anak melakukan perbuatan buruk.

3. Faktor dan hambatan ibu tiri dalam membangun karakter anak pra sekolah

Pertama lingkungan keluarga, keluarga merupakan lingkungan terdekat untuk membesarkan, mendewasakan, dan didalamnya anak mendapat kan pendidikan pertama kali (Ummi, 2008). Fungsi keluarga membina tingkah laku saling menyayangi antara anggota keluarga, karena kehidupan keluarga menjadi fase sosialisasi awal bagi pembentukan karakter anak. ketika saat berada di rumah, anak-anak yang punya ibu tiri lebih banyak menyendiri dan segala sesuatu menunggu ayah nya pulang, karena para anak-anak yang di asuh oleh ibu tiri kurang terbuka dalam berkomunikasi dengan ibu tirinya sehingga anak-anak pra sekolah yang punya ibu tiri cenderung tertutup. Harus diketahui bahwa, salah satu faktor penting untuk tercapainya pola asuh Ibu tiri dalam membangun karakter anak pra Sekolah sangat dipengaruhi oleh dukungan yang diberikan oleh keluarga, dalam hal ini ayah kandung nya, abang serta kakak-kakaknya yang telah remaja. Setiap orang tua kandung serta keluarga lainnya seperti saudara saudara kandungnya bertanggung jawab dalam keberhasilan asuhan yang diberikan oleh ibu tiri di dalam keluarga. Mareka tidak hanya dituntut dalam memenuhi kebutuhan jasmani saja melainkan juga pemenuhan kebutuhan rohani yang perlu juga diimbangi.

Kedua, pengaruh pergaulan anak yaitu Perlu diketahui bahwa ketika bermain dengan teman sebaya, anak anak yang punya ibu tiri sering ditakuti oleh kawan kawan bermain di lingkungannya, dengan mengatakan bahwa ibu tiri sangat kejam,sehingga membuat psikologi anak-anak tersebut jadi penakut di hadapan ibu tirinya, maka secara otomatis, pola asuh ibu tiri dalam membangun karakter anak anak akan mengalami kendala. Karena teman bergaul memiliki pengaruh yang sangat besar dan lebih cepat masuk dalam jiwa anak.

ketiga, lingkungan masyarakat untuk mengatasi semua perihal tersebut, sebagian dari ibu tiri berusaha dan menyakinkan pada mareka bahwasanya mereka sangat sayang dan peduli pada anak-anak tiri mareka, cuma faktor lingkungan kadang kerap terjadi setiap anak-anak yang diasuh ibu tirinya selalu di label dengan ibu tiri cerewet, sehingga kalau ada anak yang diasuh oleh ibu 
tirinya menangis selalu di anggap anak tersebut di siksa oleh ibu tirinya, padahal terkadang anak tersebut terjatuh sendiri di rumah, kesakitan lalu menangis memanggil-manggil ayahnya, namun tidak semua masyarakat berpikiran demikian, ada juga lingkungan masyarakat yang katagori baik serta toleran dan memahami persoalan.

Keempat, masalah pembawaan atau karakteristik seorang anak juga kadang dapat bertolak belakang dengan keinginan para ibu tiri untuk menjadikan anak tersebut menjadi baik melalui pola asuh nya dalam membangun karakter anak.

\section{Kesimpulan}

1. Pola asuh ibu tiri dalam membangun karakter pada anak pra sekolah adalah mendidik mareka dengan lemah lembut, ibu tiri memposisikan mareka sebagai anak kandung mereka agar mental dan karakter mareka bisa percaya diri dan seolah olah mareka masih memiliki ibu kandung. Pola asuh tidak boleh bersifat otoriter, karena akan berakibat mental dan rasa percaya diri mareka akan down.

2. Pengaruh pola asuh ibu tiri terhadap karakter anak sangat yaitu dalam bentuk tindakan preventif (pencegahan) yaitu dalam bentuk menanamkan nilai-nilai agama seperti keimanan, ibadah, akhlak, disiplin dan prinsip-prinsip luhur lainnya. Kemudian dalam bentuk tindakan repersif (aktif) yaitu memberikan perhatian yang serius terhadap berbagai hal yang dibutuhkan dan tingkah laku anak, memberikan teladan yang baik dalam hal ucapan, pakaian, perilaku, ibadah, cara bergaul dengan orang lain, memberikan rasa aman, tentram dan harmonis dalam suasana kehidupan rumah tangga. serta tindakan kuratif (pengawasan) terhadap perilaku anak baik dirumah maupun diluar rumah sehingga terbangun komunikasi yang aktif antar anggota keluarga.

3. Faktor dan Hambatan Ibu Tiri Dalam Membangun Karakter Anak Pra Sekolah adalah anak anak yang punya ibu tiri sering ditakuti oleh kawan kawan bermain di lingkungannya, dengan mengatakan bahwa ibu tiri sangat kejam, sehingga membuat psikologi anak anak tersebut jadi penakut di hadapan ibu tirinya, maka secara otomatis, pola asuh ibu tiri dalam membangun karakter anak akan mengalami kendala.

\section{Saran}

Kepada ibu, terutama ibu yang mempuyai anak tiri hendaklah memberikan kasih saying pada anakanak dengan penuh kasih sayang, walaupun bukan anak kandung dan kepada ayah, hendaklah awasi serta berikan perhatian dan pengawasan penuh kepada anggota keluarga. Berilah nasehat yang benar agar anak dapat memiliki motivasi untuk berakhlakul qarimah, beri bimbingan serta jadikan diri kita orang tua sebagai suri tauladan bagi anak anak kita.

\section{Daftar pustaka}

Ahmad, F. (2003). Psikologo Umum, Bandung: Pusaka Setia. 
Anas, S., \& Alkrienciehie, I. (2010) Pendidikan Karakter, Bandung: Pustaka Setia.

Ansori, M \& Firdaus, A, R. (2008) Pendidikan Karakter Wira Usaha, Bandung: Pustaka Setia.

Bungin, M, B. (2009). Metode Penelitian Kuantitatif: Komunikasi, Ekonomi, dan Kebijakan Publik Serta Ilmu-Ilmu Sosial Lainnya, Jakarta: Kencana.

Djamarah, S, B. (2004). Pola Asuh Orang Tua dan Komunikasi dalam Keluarga, Jakarta: Rineka Cipta.

Hurlock, B, E. 2009. Psikologi Perkembangan, Suatu Pendekatan Sepanjang Rentang Kehidupan, Edisi Kelima, Ali Bahasa, Istiwidayanti, Soedjarwo, Jakarta: Erlangga.

Purwanto, Ngalim. Psikologi Pendidikan, Bandung: Remaja Rosda Karya, 2001.

\section{Q.S Luqman Ayat 16}

Suyanto, S. (2006). Dasar-dasar Pendidikan Anak Usia Dini, Yogyakarta: Hikayat.

Syaodih, S, N. (2006). Landasan Psikologi Proses Pendidikan, Bandung, Rosda Karya.

Ummi, Ibu Tiri dalam Islam, Jakarta: Graha Media, 2008.

Chalidaziah, W., Nirwana, H., \& Alizamar. (2018) Student's self-

$$
\begin{aligned}
& \text { disclosure In: Proceeding } \\
& \text { International Conferences on } \\
& \text { Education, Social Sciences and } \\
& \text { Technology (ICESST), 14-15 } \\
& \text { Februari 2018, Padang. }
\end{aligned}
$$

Zakiyah, D. (2008). Ilmu Pendidikan Islam, Jakarta: Bumi Aksara.

Zubaedi, Desain Pendidikan Karakter, Jakarta: Kencana Prenada Media Group, 2012 